\title{
COMUNICAÇÃO
}

\section{SOBRE A NÃO INTERFERÊNCIA DA SOLUÇÃO DE CARY- BLAIR NO DIAGNÓSTICO DA CRIPTOSPORIDÍASE PELO EXAME DE FEZES}

\author{
Elaine Guizelini e Vicente Amato Neto
}

A criptosporidíase é parasitose que nos últimos anos adquiriu projeção no contexto médicoassistencial, em virtude do advento da infecção pelo vírus da imunodeficiência humana (HIV) e da síndrome da imunodeficiência adquirida (AIDS), dela decorrente. O Cryptosporidium sp, antes praticamente não cogitado em tarefas diagnósticas, passou a merecer bem maior atenção por constituir freqüente microrganismo oportunista na configuração da gravíssima afecção vinculada a expressivo déficit da defesa orgânica.

Para evidenciação do protozoário em questão, nas fezes, processos foram reativados, aprimorados ou implantadose, agora, encontram-se implantados em vários laboratórios. Além disso, no Brasil tornaram-se disponíveis muitos profissionais habilitados a propiciar correto reconhecimento desse patógeno, causador sobretudo de diarréia. A propósito, vale citar como apropriadas as técnicas da auramina, da carbol-fucsina com dimetilsulfóxido e de kinyoun.

Através desta comunicação, divulgamos um detalhe acerca do diagnóstico da criptosporidíase. Trata-se da constatação de que a solução de CaryBlair, comumente empregada para transporte de fezes que servirão para análise bacteriológica, não prejudica a visualização e identificação do Cryptosporidium sp.

Trinta amostras, provenientes de enfermos certamente infectados pelo parasita, foram analisadas mediante emprego do método de Kinyoun, com prévia colocação na solução e sem essa providência.

Pusemos as fezes, na proporção de $1 / 10$, aproximadamente, em formalina a $10 \%$; depois de 15 dias a seis meses, $3 \mathrm{ml}$ com $2 \mathrm{ml}$ de água destilada e $3 \mathrm{ml}$ com $2 \mathrm{ml}$ do líquido de Cary Blair ${ }^{2}$ serviram para aplicação da técnica de concentração do formoléter', fixação do sedimento por meio de metanol e coloração através do processo de Kinyoun ${ }^{2}$, modificado pela troca do azul de metileno pelo verde malaquita; quanto ao conservador, só mudamos um pormenor, pois acrescentamos ao original indicador fenólico, a fim de corar e diferenciá-lo de fluidos comuns.

Os resultados revelaram total concordância, desde os cinco nos quais não apareceu o Cryptosporidium $s p$ até os demais, nos quais ele foi visto, tendo inclusive ocorrido integral coincidência quanto às quantidades de oocistos encontrados.

Diante do exposto, afiançamos que a permanência da matéria fecal na solução de Cary-Blair, como sucede rotineiramente, não conturba a constatação da presença do protozoário e nem altera aspectos morfológicos indispensáveis à competente identificação. Em atividades cotidianas pode acontecer que a excreção para análise seja inadvertidamente posta no líquido referido ou corresponda, em determindo momento, à única disponibilidade.

\section{REFERÊNCIAS BIBLIOGRÁFICAS}

1. Amato Neto V, Corrêa LL. Exame parasitológico das fezes. 4a. edição, Sarvier, São Paulo, 1980.
2. Lenette EH. Manual of clinical microbiology. 4th edição, American Society of Microbiology, Washington, 1985.

\footnotetext{
Laboratório de Investigação Médica-Parasitologia do Hospital das Clínicas, da Faculdade de Medicina da Universidade de São Paulo, São Paulo, SP.

Endereço para correspondência: Dra. Elaine Guizelini. Laboratório de Investigção Médica - Parsitologia, Av. Dr. Arnaldo 455 01246-000 São Paulo, SP, Brasil.

Recebido para publicação em 30/10/91.
} 